\title{
BEVIDSTHEDEN OM KULTURARVEN OG INCITAMENTER TIL BEVARING
}

\author{
Beate Knuth Federspiel
}

«Ex præterito, præsens prudenter agit, ni futura actione deturpet»

(På fortiden bygger nutidens evne til at skabe fremtiden)

\begin{abstract}
Ovenstående citat stammer fra en talemåde, der har varet kendt siden antikken. ${ }^{2}$ Tredelingen af tiden $i$ fortid - nutid - fremtid blev i middelalderlig moralfilosofi parallelliseret til de menneskelige egenskaber hukommelse, som er forudsetningen for at bevare (mindet om) fortiden - intelligens, som rummer evnen til at erkende nutiden, og - fremsyn, som satter mennesket $i$ stand til at se ind i fremtiden.
\end{abstract}

Selv om den citerede talemåde ikke oprindeligt tog sigte på kulturarven, rummer den en erkendelse, som i en nutidig forståelse af kulturarvsbegrebet udmærket kunne danne udgangspunkt $\mathrm{i}$ arbejdet med kulturarven - uanset om man beskæftiger sig med indsamling, formidling eller bevaring. Kulturarven er vores hukommelse. Uden den mister vi evnen til at erkende nutiden og fortaber således vores fremtid.

Det er $\mathrm{i}$ vores tid almindeligt anerkendt, at kulturarven har en afgørende betydning

I forrige nummer af Nordisk Museologi $(1998, \mathrm{nr} .1)$ findes to artikler om begrebet kulturarv'. Der er tilsyneladende i museumskredse stor modstand mod at bruge ordet kulturarv. For nylig deltog jeg i Nationalmuseets 1. seminar i det Museologiske Netværk, som er en arbejdsgruppe, dannet på initiativ fra Nationalmuseets formidlingschef Jette Sandahl. Mit indlæg på seminaret havde ovennævnte titel. Efter seminaret blev jeg bekendt med de to artikler om begrebet kulturarv i forrige nummer af Nordisk Museologi. Eftersom indlæggene fra seminaret nu offentliggøres i Nordisk Museologi $1998 \mathrm{nr} .2$, finder jeg det nødvendigt at gøre opmærksom på, at skønt mit indlæg ikke oprindeligt var ment som et svar på Hudson's og Witt's artikler, kan det udmærket ses sådan. Og lad det være sagt straks: jeg deler ikke de to forfatteres angreb på betegnelsen kulturarv. For mig har ordet stadig den betydning af hukommelse og identitet, af umistelige værdier, som end ikke alverdens profitmagere formår at ødelægge (jvf. Hudson p. 12 ff.). I indlægget forsøger jeg at trække de historiske perspektiver omkring kulturarvsbegrebet op; hvad jeg især finder væsentligt - på baggrund af de to artikler $i$ Nordisk Museologi nr. 1 - er de allerseneste diskussioner om kulturarvsbegrebet i to meget aktuelle og indflydelsesrige dokumenter: Naradokumentet om Autenticitet (1994), og rapporten (1995) fra Verdenskommissionen for Kultur og Udvikling, nedsat under Unesco (se note 3). $B K F$. 
for identitet og selvforståelse ikke blot hos det enkelte menneske, men i hele folkeslag. I takt med udbredelsen af den erkendelse er opmærksomheden om bevaringen af den kulturelle arv - og de åbenlyse problemer der er forbundet hermed - blevet skærpet.

I 1980 'erne begyndte sloganet «bevaring som udvikling" at dukke op. På det tidspunkt var den tanke tæt forbundet med materiel fremgang: "Bevaring betaler sig» hed det i samme åndedrag. I 1990'erne har sammenhængen mellem kulturarv og udvikling fået en lidt anden - og mere positiv - drejning: Den kan sammenfattes med et citat fra den nyligt udkomne rapport fra Verdenskommissionen for Kultur og Udvikling, nedsat under UNESCO, som analyserer de mange aspekter mellem kultur og udvikling. Rapporten beskriver bl.a. den kulturelle arvs rolle i forhold til udvikling således: "..at øge menneskers viden om sig selv ved at vise sammenhængen mellem kulturer og forklare disse ved hjælp af kulturarvsbegrebet.» ${ }^{3}$

Bevaringen af kulturarven er ikke længer alene ensbetydende med at bevare status quo - selv om det egentlig er denne nostalgiske betydning, der ligger $\mathrm{i}$ ordet bevaring. I overensstemmelse med det nye syn på de tætte sammenhænge mellem udvikling og kultur er det dette: kulturen som bærer af traditioner, ideer, forestillinger og adfærd, der retfærdiggør den opfattelse, som er blevet udbredt i $1990^{\prime}$ erne: at bevaring ikke bare er ensbetydende med at fastfryse en tilstand eller et stadium, men derimod ensbetydende med udvikling, fordi bevaring i forhold til den opfattelse af kultur og kulturarv skaber kontinuitet. ${ }^{4}$

Det er formålet med dette indlæg at forsøge at se, hvordan man gennem tiden har forholdt sig til det, der var overleveret fra fortiden. Først sent i historien har man forholdt sig til begrebet kulturarv. ${ }^{5}$ Mennesker har til alle tider forholdt sig til det, der var overleveret fra fortiden. Det er blevet brugt - når vi taler om den materielle arv, måske slidt op, for til sidst ikke længere at eksistere. Eller det er, trods ihærdig brug, blevet værnet om - bevaret - og grundene er mange og meget forskellige, endog for den samme slags genstande eller monumenter. Den immaterielle arv er det straks vanskeligere at omtale i sådanne vendinger. Man kan opfatte den som et aspekt af den materielle kulturarv. Den har været til stede i form af forestillinger, måder at handle og tænke på, uhåndgribelige værdier, som har formet de normer, hvorefter mennesker lever og har levet i forskellige kulturer, og som også har formet de forskellige samfunds kunstværker, arkitektur og mere dagligdags genstande.

\section{KULTURARVSBEGREBET}

Selve betegnelsen kulturarv er historisk set ret ny. Det er almindeligt antaget, at den hører hjemme i 1700-tallet og opstod i takt med en øget bevidsthed om betydningen af fortidens monumenter, kunstværker osv. som igen havde tæt forbindelse med udviklingen af arkæologien som en selvstændig, videnskabelig disciplin.

Kulturarvsbegrebet er ikke konstant. Fra Haag Konventionen af $1954,{ }^{6}$ over Venedig Charteret (1964) Verdensarvkonventionen $(1972)^{8}$ og Nairobi Rekommendationen $(1976)^{9}$ til UNESCO's rapport om Kultur og Udvikling (1995) ${ }^{10}$ kan man følge, hvordan forestillingerne om kulturarven og dens betydning er blevet stadig udvidet 
i forhold til de forestillinger, der knyttede sig til begrebet før 2 . verdenskrig.

Ordet kulturarv dækker ikke alene monumenter, kunstværker og genstande, men også større samlede helheder som bymæssige bebyggelser og hele byer. Det, som i Venedig Charteret kaldes 'historic sites' er med Nairobi Rekommendationen suppleret med 'historic areas'. Dermed menes de historiske områder, som er en del af menneskers daglige liv, og som også udgør rammerne for deres aktiviteter. I kraft af det, får sådanne områder en særlig, menneskelig dimension, som det hedder i Nairobi Rekommendationens indledning.

I den definition, som er brugt i Verdensarvkonventionen, omfatter kulturarven desuden natur og miljø i meget bred forstand - såvel egentlig natur som kulturlandskaber. I rapporten fra Verdenskommissionen for Kultur og Udvikling anlægger man en endnu bredere, antropologisk synsvinkel på kulturarvsbegrebet, idet man erkender, at det stadig overvejende er "de æstetiske og historiske kriterier, der styrer vores opfattelse af kulturarven.» (s.185). Derfor er det stadig de store monumenter og kunstværker, der er i focus, når det gælder bevaringen af kulturarven. I rapporten slås et slag for det, der betegnes den immaterielle kulturarv-bl.a. lokale traditioner, sprog, stednavne og deres sammenhæng med et givet landskab. " Der findes også kulturer, som ikke forbinder kulturarv med noget materielt.

I overensstemmelse med denne brede, antropologiske opfattelse af kulturarvsbegrebet er anerkendelsen af mangfoldigheden i kulturarven - kulturel pluralisme - et af nøgleordene til forståelsen af det nutidige kulturarvsbegreb. Kulturel diversitet er et andet af nøglebegreberne, autenticitetet tredie. Det afspejles tydeligt såvel i rapporten fra Verdenskommissionen som i de seneste diskussioner på bevaringsområdet. $^{12}$ Det er en udbredt opfattelse, at mangfoldigheden og forskelligheden i kulturer - både kulturen som tradition (kulturarven) og som dynamisk kilde til forandring - som det udtrykkes i Verdenskommissionens rapport, (p.14) er en uerstattelig ressource på linje med biodiversitet i naturen. Det er også erkendt, at respekten for kulturel forskellighed er en forudsætning for fred og stabilitet, og dermed for videre menneskelig udvikling. Dermed lægger rapporten sig op ad det grundsyn, Brundtlandrapporten anlægger, som forudsætning for det, som i Brundtlandrapporten kaldes 'bæredygtig udvikling' (sustainable development) - undertitlen på Verdenskommissionens rapport er da også (i den danske oversættelse: Kulturens Brundtlandrapport).

I bevaringssammenhæng betyder det, at de universelle principper, man indtil for få årtier siden tilstræbte at håndhæve på internationalt plan, har måttet revideres. Således var det selve anledningen til konferencerne i Bergen og Nara, at Verdensarvkommitteen selv anbefalede en kritisk evaluering af principperne for optagelse på Verdensarvlisten (se i øvrigt note 32). Efter Nara er opfattelsen internationalt den, at bevaring ikke bør ske ud fra nogle universelle principper, men ud fra det enkelte samfunds skøn om, hvad der karakteriserer dets kulturarv. Det er i fuld overensstemmelse med det ændrede udviklingsbegreb, der ikke længer alene anlægger materiel fremgang som målestok, men ser bevaring af kulturværdier som en afg $\varnothing$ rende forudsætning for udvikling. ${ }^{13}$ 


\section{HISTORIEN - FØR RENAISSANCEN}

Langt tilbage $\mathrm{i}$ historien har vi efterretninger - skriftlige vidnesbyrd eller materielle spor - om forsøg på at værne om det overleverede. Den måde, det er sket på gennem tiden, afspejler det, som Jukka Jokilehto kalder "the maturation of ethical consciousness». ${ }^{14}$

Kendskabet til den proces kan skærpe bevidstheden om vores egne holdninger til det overleverede. Det sætter os også i stand til at aflæse tidligere indgreb: hvor i historien skal de placeres, hvorfor ser de sådan ud, hvad afspejler de o.s.v. Kendskabet til bevaringens historie ansporer os - både på et musealt og et bevaringsteoretisk plan til at reflektere over spørgsmålene: hvorfor bevarer vi, hvad bevarer vi, for hvem bevarer vi?

Før renaissancen tegner der sig endnu ikke et sammenhængende billede af en kronologisk udvikling i bevaringshistorien. Dertil er efterretningerne for spredte. Der tegner sig nogle incitamenter, som menneskeligt set - er meget grundlæggende. ${ }^{15}$

Et incitament til bevaring, der er så gammelt som det menneskelige samfund er nytte eller brugsværdi. Så længe redskaber, bygninger, veje, samfærdselsmidler o.s.v. har en brugs- eller nytteværdi, sålænge har man bestræbt sig på at vedligeholde og dermed bevare dem.

Et andet meget grundlæggende kriterium for bevaring er det, man kunne kalde symbolvardien eller kult- eller religiøs værdi. Pyramiderne er et eksempel tidligt i historien på bevaring i kraft af deres symbol- eller kultværdi. Eksemplerne er mange gennem oldtid og middelalder. Gennem hele middelalderen var det Roms symbolværdi, først som hovedstad i antikkens verdensimperium, senere som Kristenhedens hovedstad, der lå til grund for bevaringen af byens monumenter naturligvis ved siden af brugsværdikriteriet. Overbevisningen om byen Roms symbolske betydning var så udbredt, at fremmede herskere i hele Europa ligefrem rekvirerede antikke arkitekturdele eller fragmenter af skulpturer, som f.eks. kunne bygges ind på fremtrædende pladser i deres egne bygningsværker eller opstilles i villaen eller haven - en fænomen der kendes lige siden 700-tallet op gennem middelalder og renaissance. Et nutidigt parallelt eksempel er Berlinmuren, som efter dens fald i 1989 blev solgt i småstykker på grund af det symbolske $i$ at muren og alt, hvad den havde stået for, nu var brudt og kunne fordeles i småstykker.

Fra de antikke historikere Herodot, Strabo og Pausanias, der alle skrev i det 2. årh. før Kr. ved vi, at efter slaget ved Platææ (5.årh. f.Kr.) blev ruinerne af de templer, perserne havde ødelagt, efterladt i deres fragmenterede tilstand som mindesmærker over persernes overgreb. Dele af søjleskafter og andre arkitekturdele fra nogle af de ødelagte templer blev tilmed bygget ind i Akropolis' nordmur på Perikles' tid som minder om begivenheden. ${ }^{16}$ Mindet om en begivenhed kunne altså så tidligt i historien være kriteriet for bevaring - også i betydningen: bevaring af fragmenter. Det er den samme tanke, der ligger bag bevaringen af den udbombede kirke i Berlin: Friedrich Wilhelm Gedächtniskirche, der er efterladt i sin fragmenterede tilstand som minde om de allieredes bombninger ved 2 . verdenskrigs slutning. Symbolværdien spiller naturligvis også en afgørende rolle her. 
Mindet om en person kunne også være et incitament til bevaring. Et kendt eksempel tidligt i historien er Hadrians rekonstruktion af Pantheon, som oprindeligt var opført af Agrippa i år 25 f.Kr. men som i løbet af blot halvandet århundrede bogstaveligt var gået til. Hadrians rekonstruktion, som han stadig opfattede som Agrippas værk, var ment som en hyldest til Agrippa.

De kriterier, som er nævnt her, implicerer et problem af filosofisk art. De indebærer vedligeholdelse over mange generationer - eller tilmed rekonstruktion. Langsomt, eller pludseligt, erstattes alt oprindeligt materiale af nyt, samtidig med at genstanden eller monumentet dog bibeholder sin oprindelige funktion eller betydning.

Det problem kaldes bevaringens esoteriske dimension. Esoterisk betyder 'kun for indviede' . Den esoteriske dimension går på de ikke-fysiske kvaliteter ved en genstand eller et monument. Forklaringen på problemet er, at sålænge en tradition fortsætter, kan man genopføre, nymale, reparere o.s.v. uden at det går ud over autenticiteten, fordi det sker samtidig med, at traditionen respekteres. Autenticiteten identificeres ikke i kraft af materialets oprindelighed, men i kraft af processen og kontinuiteten i traditionen.

Den esoteriske dimension og den særlige betydning af autenticitet, der knytter sig til den, er særlig tydelig i de kulturer, som ikke betragter kulturarv som noget materielt, men derimod som en viden og en håndværksmæssig kunnen. Det gælder f.eks. visse af stillehavskulturerne, hvor fremstillingen af en lang række genstande er tæt forbundet med ritualer. Genstanden kan f.eks. destrueres direkte efter brug, men ved fremstillingen af den næste, er 7 der stadig tale om en autentisk genstand.

\section{- EFTER RENAISSANCEN}

Fra renaissancen og frem til vores egen tid tegner billedet af bevaringens historie sig stadigt tydeligere. Med renaissancen begynder spiren til det, man kunne kalde en 'moderne' bevidsthed om bevaringen af det, der er overleveret fra fortiden. Den italienske renaissancedigter og historiker Petrarca har en stor andel i den begyndende ny bevidsthed. Ved en lejlighed i 1337 besøgte han Rom, og i hans beskrivelser af de indtryk, besøget gjorde på ham, finder man - som noget nyt - en bevidst skelnen mellem den antikke verden og den nye verden. Med Petrarca begynder et nyt historiesyn at tage form. Netop historiesynet og skabelsen af en historisk bevidsthed er afgørende elementer i forestillingerne om en arv fra fortiden og udviklingen af holdninger til den. ${ }^{17}$

Petrarcas tanker om de romerske antikke monumenter - som vidnesbyrd om byens fordums storhed - og især hans begrædelse af den tabte storhed, kom til at bestemme opfattelsen af fortiden, og dermed historiesynet, langt op i tiden. Tankegangen blev fortsat blandt 1400-tallets humanister, og kom til at danne grundlaget for de historiske og antikvariske studier, som efterhånden gjorde studiet af historien og arkæologien til selvstændige discipliner.

I løbet af 14- og 1500-tallet samlede humanister stadig mere materiale om fortiden og bidrog gennem deres indsamling til et bestemt syn på historie og arkæologi. Det var især Roms storhed, de dyrkede, og ruinerne som billeder herpå. Dermed vok- 
8 sede også ønsket om at beskytte det overleverede fra yderligere forfald.

Den bevaringspraksis, der kendetegner 15- og 1600-tallet er temmelig håndfast. Selv om antikkens monumenter blev opfattet som forbilleder, man kunne tage ved lære af, blev de også set som milepæle, der skulle passeres. Det betød bl.a. at man i vid udstrækning kompletterede og ombyggede med den hensigt at give kunstværket eller bygningen fornyet funktion.

Særlig tankevækkende er billedhuggeren Benvenuto Cellinis selvbiografiske beretning om, hvordan han kompletterede en antik torso, og tilmed tilføjede en ørn, så han fik den forvandlet til en Ganymedes. En nutidig læser må det forekomme paradoksalt, at hans motivation var denne: "..den store mesters snille råber til mig om hjælp." ${ }^{18}$

Komplettering var en udbredt praksis langt op i 1800-tallet, selv længe efter at den tyske arkæolog og kunsthistoriker Johan Joachim Winckelmann var begyndt at argumentere imod kompletteringer. Winckelmanns antikvariske kritik kom alligevel til at få afgørende indflydelse langt ind i det efterfølgende århundrede, med en særlig udløber i England, hvor John Ruskin og William Morris fortsatte videreudviklingen af Winckelmanns tanker om bevaringen af fortidens monumenter og kunstværker. ${ }^{19}$

Den franske revolution i 1789 kom til at betyde et ændret syn på kunstværker og monumenter. I kølvandet på revolutionen skete der en demokratisering af den kulturarv, som ellers havde været forbeholdt en ganske lille overklasse. 1793 udstedte Nationalforsamlingen et dekret, som beskyttede kunstværker og monumenter med den begrundelse, at de havde betyd- ning for opdragelsen af kommende generationer og for Frankrigs internationale position - incitamenter, som har haft gyldighed siden. Forståelsen af den kulturelle arv som et falles anliggende begynder også at tage form her.

Revolutionen var i høj grad medvirkende til at skabe en ny forståelse for de dokumentariske og kunstneriske værdier i den kulturelle arv, og dermed opstod også et behov for at registrere, klassificere og inventarisere. Faktisk resulterede den udvikling i oprettelsen af nogle af Europas første offentlige kunstmuseer - ejet af offentligheden og tilgængelige for alle.

På grund af nogle historiske og politiske omstændigheder kom Frankrig gennem 1800-tallet til at blive et foregangsland på monumentbevaringsområdet. ${ }^{20}$ Allerede i 1790 'erne var registreringen af monumenter begyndt, og den fortsatte i Napoleonstiden. Først i 1837 med oprettelsen af 'La Commission des Monuments Historiques', kom der gang i konkrete bevaringstiltag. Viollet-le-Ducs mange hårdhændede restaureringer af en lang række af Frankrigs største og mest betydningsfulde monumenter blev gennemført i tæt samarbejde med kommissionen.

Sidste halvdel af 1800-tallet var præget af en meget hårdt optrukket konfrontation mellem en radikal anti-restaurerings bevægelse og en lige så radikal tilbageføringspraksis, som havde kendetegnet monumentbevaringen fra århundredets begyndelse. Den hårdhændede stilrestaurering skal især ses på baggrund af en vældig interesse for middelalderen, som udsprang af de urolige tider under og efter Napoleonskrigene. I hele Europa så man middelalderen som en forbilledlig periode - middelalderpasticher og gotiske stilres- 
taureringer satte deres nostalgiske præg på monumentbevaringen.

Med de store offentlige museer, som begyndte at opstå fra slutningen af 1700 tallet, begyndte også bevaringen af kunstog kulturgenstande at ændre karakter. Meget forenklet sagt ligger spiren til det, som langt senere skulle få betegnelsen videnskabelig konservering her. Oplysningstidens tanker om naturvidenskaben som nøglen til fremskridt og øget indsigt smittede i løbet af 1800-tallet af på holdningen til bevaringen af kunstværker og arkæologiske genstande.

Indtil da havde det været malere, der reparerede kunstværker, billedhuggere, der reparerede skulptur, arkitekter, der restaurerede bygninger osv. Med 1800-tallet begyndte restaurering at skille sig ud som et selvstændigt område, med særlige fagfolk. Selvom vægten i vid udstrækning stadig lå på 'reparation', begyndte opfattelsen langsomt at ændres, især under indtryk af to afgørende faktorer: den stærkt stigende forurening, som industrialiseringen medførte, og de enorme mængder af især arkæologisk materiale, som akkumuleredes i Europas museer i hastigt tempo. Kemikere blev i stadig stigende grad involveret i løsningen af nedbrydningsproblemer, og vægten skiftede gradvist fra reparation til konserverende behandlinger især inden for det arkæologiske område. ${ }^{21}$

Fra slutningen af 1700-tallet begyndte de stærkt risikable, tekniske løsninger at blive anvendt på malerier - ofte med langt alvorligere konsekvenser end tidligere tiders overmalinger, ændringer af formater osv. Metoder som rentoilering, parkettering, transport og marouflage hører hjemme her, og de udførtes endda ikke altid for kunstværkets skyld, men ofte for at demonstrere dristighed og ekspertise. Der eksisterer ikke så få beretninger om 'stjernerestauratorer'. ${ }^{22}$

Rensningsmetoderne var lige så radikale, som de var effektive. Kraftige slibemidler - som sand eller pimpsten - kombineret med stærkt ætsende væsker (f.eks. lud) var almindeligt anvendt. ${ }^{23}$

Der var dog også eksempler på restauratorer, som benyttede metoder, der i deres hensyn til originalen pegede langt frem i tiden. Giovanni Battista Bellori, som var direktør for Academia di San Lucca i Rom i 2. halvdel af 1600-tallet, demonstrerede stor interesse for bevaring og stod bl.a. bag maleren Carlo Marattas tilbageholdende restaureringer af en række barokke altertavler. I et enkelt tilfælde er tilmed dokumenteret et så moderne fænomen som præventiv konservering, idet Maratta fik udvirket flytning af en del af malerierne fra en bestemt kirke i Loreto, angiveligt for at forhindre yderligere nedbrydning under de dårlige forhold i kirken. ${ }^{24}$

Bartolommeo Cavaceppi, som var en kendt og skattet restaurator af antik skulptur i sidste halvdel af 1700-tallet, skrev en af de tidligst kendte håndbøger om restaurering. ${ }^{25}$ Her taler han bl.a. om værkets originalitet og om at underordne sig kunstværket. Dokumentation i form af tegninger var også en del af hans arbejdsmetode. I øvrigt var Cavaceppi nær ven af Winckelmann, og stærkt påvirket af hans ideer om restaurering.

Fra begyndelsen af 1800-tallet begyndte udgivelsen af en række væsentlige bøger om restaurering. De afspejler bl.a. at man foruden de tekniske løsninger og restaurerende/repararende indgreb så småt begyndte at beskæftige sig med de mere principielle holdninger til bevaring. ${ }^{26}$ 
10 Både i bevaringen af kunst- og kulturgenstande og i monumentbevaringen viste der sig ved overgangen til 1900-tallet en stadig større tilbageholdenhed overfor restaurering som sådan. Den første internationale resolution om bevaring - Carta del Restauro fra 1883 - lagde sig tæt op ad Ruskins tanker og lagde klart vægten på de konserverende behandlinger. ${ }^{27}$

Det var også her - ved slutningen af 1800-tallet - de første museumslaboratorier, ledet af kemikere, begyndte at blive oprettet, og naturvidenskabelige metoder i stigende grad taget $\mathrm{i}$ brug til undersøgelse af nedbrydningsfaktorer med henblik på konserverende behandlinger. ${ }^{28}$ Tendensen fortsatte gennem de første par årtier af 1900-tallet indtil 1. verdenskrig, som havde to væsentlige effekter i konserveringshistorisk sammenhæng: dels medførte verdenskrigen de hidtil mest omfattende, samlede ødelæggelser af kulturejendom, dels satte krigen fart $\mathrm{i}$ udviklingen af ny teknologi, nye materialer osv.

Tiden mellem de to verdenskrige er den periode, hvor de nutidige forestillinger om bevaring bliver dannet. Meget kort kan de forestillinger karakteriseres sådan, at bevaringen af den materielle kulturarv gælder dens materielle oprindelighed, og at dette betyder at forsinke nedbrydning ved at forstå nedbrydningens mekanismer og ved at anvende videnskabelige behandlingsmetoder samt forebyggende behandlinger. Det var i 1920 'erne og -30'erne disse principper blev knæsat. Foregangsmændene i den naturvidenskabelige tilgang til kunstværker - R.J.Gettens og George Stout havde deres hovedindsats her. De stod bl.a. bag udgivelsen af Technical Studies in The Field Of Fine Arts, forløberen for Studies in Conservation. Museer og
Kunstinstitutter oprettede i de år laboratorier med tilknyttede, betydende videnskabsfolk.

På det teoretiske plan var det også her, de store internationale kongresser om bevaring fandt sted. The International Museums Office (forløberen for ICOM) arrangerede i 1930 en international konference om videnskabelige metoder $\mathrm{i}$ undersøgelsen af kunstværker. På det samme møde blev det besluttet at arrangere endnu en international konference med focus på monumentbevaring. Det blev Athenkonferencen, hvis vigtigste resultat var Athen Charteret af 1931, som blev forløberen for Venedig Charteret - begge betoner konserverende indgreb frem for restaurerende. Siden er vægten flyttet fra konservering til præventiv konservering. Det er i stigende grad de forebyggende foranstaltninger, dvs. så lidt konkret indgriben i monumenter og kunstværker som muligt, men derimod forbedrede (opbevarings-) forhold, der nu sættes som mål.

Organiseringen af bevaringsområdet kan også - delvist - ses som effekter af de to verdenskrige. Efter 1. verdenskrig oprettedes The International Museum's Office (1926), som rangerede under The International Committee for Intellectual Cooperation (1922) - forløberen for UNESCO, som blev dannet i 1945. Under UNESCO organiseredes ICOM, International Council of Museums (1946), ICCROM, International Center for the Study of the Preservation and Restoration of Cultural Property (1956) og ICOMOS, International Council of Monuments and Sites (1964). I regi af de store organisationer formuleres de internationale dokumen ter om kulturarven og bevaringen af den. ${ }^{29}$ Generelt sagt er det i vort århundrede, sys- 
tematiseringen, organiseringen og lovgivningen på bevaringsområdet finder sted.

Teoridannelserne hører også hjemme her. Især kunsthistorikerne Alois Riegls og Max Dvoraks teorier fik betydning langt frem i tiden. I deres syn på kultur og historie stod de i gæld til den tyske filosof og historiker Johan Gottfried Herder, som ved slutningen af 1700 -tallet havde udviklet forestillingen om kulturel pluralisme.

Riegls teori. om bevaring var styret af respekten for de forskellige historiske faser, og essencen af den var et minimum af indgriben. Det var en fornyelse i forhold til den herskende opfattelse: at monumenter burde bevares i kraft af deres historiske og især nationale betydning. Riegls motivation for bevaring var langt bredere. Han arbejdede ud fra en Hegelsk dialektik og opererede bl.a. med en «Menscheitsgefühl», i hvilken kunstværker og monumenter ikke betragtes som tilhørende en bestemt nation eller kultur, men derimod hele menneskeheden. Det blev og er stadig - grundtanken i det 20. århundredes internationale erklæringer og lovgivning på bevaringsområdet: «the cultural heritage of each is the cultural heritage of all.» ${ }^{30}$ Den tanke er også selve grundlaget for UNESCO.

Man kan se de to verdenskrige i vores århundrede som de ydre omstændigheder, der afstedkom behovet for de store internationale organisationer, hvis fælles mål har været - og er - at løse konflikter uden brug af våben (Nationernes Forbund 1919, og de Forenede Nationer 1945). Efter 1945 er der især lagt vægt på det internationale samarbejde på det kulturelle, uddannelsesmæssige og videnskabelige område (UNESCO); det afspejles også i den struktur af organisationer til fremme af det internationale samarbejde, som er opstået efter 1945 .

\section{DET SENESTE ARTI}

1990 'erne er af UNESCO erklæret for kulturens årti. I 1992 nedsattes Verdenskommissionen for Kultur og Udvikling, en kommission på linje med Brundtlandkommissionen, der havde behandlet miljøproblemerne på verdensplan. Verdenskommissionens rapport: Our Creative Diversity, som udkom i 1995 (se note 3), må siges at afspejle den opfattelse af kultur og kulturarv, som kendetegner de allersidste år af det 20. århundrede. Betoningen af sammenhængene mellem kultur(arv) og udvikling har aldrig været stærkere.

Såvel UNESCOs rapport som de seneste internationale dokumenter på bevaringsområdet viser, at nøglebegreberne i nutidens forståelse af kulturarven er: kulturel pluralisme, kulturel diversitet og autenticitet. ${ }^{31}$ Siden 1994 har især autenticitetsbegrebet været $\mathrm{i}$ focus $\mathrm{i}$ den internationale debat om varetagelsen af kulturarven. Kulminationen er foreløbig Naradokumen tet om Autenticitet, som blev vedtaget på Nara Konferencen om Autenticitet i 1994.

I respekten for andre kulturer er autenticitetsbegrebet efter Nara betydeligt udvidet, ligesom betydningen af mangfoldigheden og forskelligheden i kulturarven er stærkt fremhævet. Det hedder bl.a. (stk.5):

The diversity of cultures and heritage in our world is an irreplaceable source of spiritual and intellectual richness for all humankind. The protection and enhancement of cultural and heritage diversity in our world should be actively promoted as an essential aspect of human development. 
12 Naradokumentets måske væsentligste bidrag til nutidens syn på kulturarven er den opfattelse af autenticitet, det udtrykker. I Venedig Charteret var autenticitetsbegrebet tydeligt vestligt orienteret - traditionelt har den vestlige verden lagt vægt på materiel autenticitet. Selv om autenticitet stadig er kriteriet for optagelse på The World Heritage List, ${ }^{32}$ er det erkendt, at autenticitet er et relativt begreb. Det har ikke nogen given definition - definitionen beror på den kulturelle sammenhæng, hvori det bedømmes. I Naradokumentets stk. 11 siges det bl.a.

... it is not possible to base judgements of value and authenticity on fixed criteria.On the contrary, the respect due to all cultures requires that cultural heritage must be considered and judged within the cultural context to which it belongs.

Med erkendelsen af de grundlæggende begreber: kulturel pluralisme, kulturel diversitet og autenticitet og med forståelsen af den kulturelle arvs rolle i den videre menneskelige udvikling, står nutidens konservatorer og museumsfolk overfor en særdeles vidtrækkende og forpligtende opgave: som bevarere af kulturarven er vi med til at definere fremtiden. Perspektiverne er lange - både bagud og fremad i tid. Perspektiverne, som de er ridset op i det foregående viser, at diskussionen om, hvad kultur og kulturarv er, og hvilke forskellige betydninger, de to betegnelser kan eller bør tillægges, aldrig er slut. De viser også, at det er vigtigt og nødvendigt at diskutere videre - med det mål at skærpe opmærksomheden og tankerne om, hvordan vi bruger (i mange betydninger af ordet) det, der er overleveret fra fortiden, det, som danner grundlag for vores fore- stillinger, adfærd og værdier. Om man foretrækker at kalde det kultur eller arv eller kulturarv eller noget helt andet, er i og for sig underordnet. Vi ved jo godt, hvad det drejer sig om - og hvad det gælder. 
NOTER

1. Kenneth Hudson: What I think of as my Heritage. Nordisk Museologi, 1998, nr.1 p.9-16 og Torben Witt: Kulturarv - hvad taler vi om ?, samme p.17-24.

2. Oprindelsen er formodentlig hos Platon, se Burlington Magazine, XLIX, 1926, p.178 note 6.

3. Global Etik, p.194 Verdenskommissionen for Kultur og Udvikling blev nedsat under UNESCO i 1992, og udgav tre år senere rapporten: Our Creative Diversity, rapporten er oversat til dansk med titlen: Global Etik. Kulturens Brundtland rapport og udgivet af Mellemfolkeligt Samvirke i 1998.

4. Se også Jukka Jokilehto's fremstilling i: Cultural Heritage. Diversity and Authenticity. ICCROM, December 1994, og samme forfatter: Authenticity. A General Framework for the Concept. The Nara Conference on Authenticity in Relation to the World Heritage Convention. Nara, Japan, November 1994, Publ. by UNESCO, ICCROM, ICOMOS and The Agency of Cultural Affairs, Japan, 1994 samt: Bengt O. H. Johansson: Historien som styrmedel. Kulturmiljövård, nr.4, 1990, p.7ff.

5. 'Kulturarv' er en oversættelse af det engelske 'cultural heritage'. 'Heritage' stammer fra oldfransk 'heritage'. Den latinske oprindelse er hereditas = arv. I Webster er anført tre betydninger, hvoraf de to er relevante i denne sammenhæng: «a) property that is or can be inherited, b) something handed down from one's ancestors or the past, as a characteristic, a culture, tradition etc. (fra: Webster's New Universal Dictionary of the English Language. Unabridged. New York 1976).

6. Convention for the Protection of Cultural Property in the Event of Armed Conflict (The Hague Convention), 1954. Teksten findes på internetadressen: www.unesco.org.

7. International Charter for the Conservation and Restoration of Monuments and Sites /The
Venice Charter), 1964 Teksten findes på internetadressen: www.international.icomos.org.

8. Convention Concerning the Protection of the World Cultural and Natural Heritage (The World Heritage Convention), 1972 Teksten findes på internetadressen: www.unesco.org, (se også note 28).

9. Recommendation Concerning the Safeguarding and Contemporary Role of Historic Areas, Nairobi 1976 Teksten findes på internetadressen: www.unesco.org.

10. Op.cit. note 3.

11. Op.cit. note 3 kapitel 7.

12. Se især beretningerne fra konferencerne i Bergen og Nara 1994, (K.E.Larsen (ed.)Oslo, 1994 og Nara 1994).

13. FN har i sit udviklingsprogram UNDP defineret menneskelig udvikling som «en proces, der skal give adgang til flere valgmuligheder» (citeret fra Global Etik, p.10). Som det gøres opmærksom på i Verdenskommissionens rapport, har kulturen en central rolle i FNs udviklingsbegreb, uden at det dog er særligt klart formuleret i UNDP.

14. Jokilehto, ICCROM 1994, indledningen.

15. Den historiske fremstilling i dette afsnit støtter sig i høj grad på den fremstilling af bevaringens historie, som Jukka Jokilehto har givet i de værker, der er anført i litteraturlisten.

16. Se især Jokilehto, A History of Architectural Conservation, Vol I, kapitel 3.

17. Se især Jokilehto, ICCROM, 1994.

18. Benvenuto Cellinis selvbiografi, danske udgave, p.359.

19. Se bl.a. Pevsner, 1969 og Tsudi-Madsen, 1976.

20. Se især Johnsson, 1976.

21. Se Clavir, 1998.

22. Se D.Hartin: An Historical Introduction to Conservation, i Shared Responsibility National Gallery of Ottawa, 1989 og Schiessl, 1998.

23. Se T. Caley: Aspects of Varnishes and the Cleaning of Oil Paintings before 1700. IIC 
14 Brussels Congress, 1990 Cleaning, Retouching and Coatings. P.70-73 og: W.Percival-Prescott: Long Lost Relations and New Found Relativities: Issues in the Cleaning of Paintings. Appearance, Opinion, Change. Evaluating the Look of Paintings. UKIC Conference, London 1990, p.813.

24. Jokilehto, 1986, Vol I, p.65 ff.

25. Jokilehto, 1986, Vol.I, p.91 ff.

26. Schiessl, 1998, p.146.

27. Johnsson, 1976, p.216 ff.

28. Clavir, 1998.

29. Se note 6-9.

30. Naradokumentet om autenticitet, stk 8.

Dokumentet findes på internet: www.international.icomos.org.

31. Se bl.a. Naradokumentet om autenticitet, 1994 og San Antonio Deklarationen, 1996, for det sidste dokument se: www.icomos.org/docs/san_antonio.html.

32. I 1972 vedtog UNESCO på sin generalforsamling The Convention Concerning the Protection of the World Cultural and Natural Heritage (i daglig tale: The World Heritage Convention, på dansk: Verdensarvkonventionen). Verdensarv-

konventionen repræsenterer den bredeste internationale lovgivning på bevaringsområdet. Samtidig nedsattes The World Heritage Committee, hvis opgave det blev at definere de kriterier, der burde gælde for, at et monument eller en lokalitet kunne optages på The World Heritage List, som oplister de monumenter og lokaliteter, som skønnes at have universel værdi for hele menneskeheden. I 1977 besluttede kommitteen, at kulturarv, som var nomineret til Verdensarvlisten, skulle bestå en test of authenticity. Instrumentet til bedømmelsen var The Operational Guidelines for the Implementation of the World Heritage Convention. Heri er defineret flg.aspekter af autenticitet i forhold til: - «design, material, workmanship and setting» (Operational Guidelines, art.24b). Siden da har det vist sig, at begrebet er altfor snævert $\mathrm{i}$ forhold til kulturarven på globalt plan. I 1992 anbefalede kommitteen så en kritisk evaluering af begrebet. Resultatet var et indledende møde i Bergen med temaet: Autenticitet i forhold til Verdensarkonventionen, og et efterfølgende internationalt møde i Nara i Japan med samme tema. (For de to konferencer se litteraturlisten). 


\section{LITTERATUR}

Appearance, Opinion, Change. Evaluating the Look of Paintings, UKIC conference, 1990, London.

Brundtlandrapporten: Vor Falles Fremtid.

Brundtlandkommissionens rapport om Miljø og Udvikling. FN-forbundet og Mellemfolkeligt Samvirke. 1988.

Clavir, M.: The Social and Historic Construction of Professional Values in Conservation. Studies in Conservation, 43, 1998, p.1-8.

Cleaning, Retouching and Coatings. Preprints of the Contributions to the Brussels Congress, september 1990, IIC, London 1990.

Fielden, B.M. and J.Jokilehto: Management Guidelines for World Cultural Heritage Sites. ICCROM, Rome 1993.

Global Etik. Kulturens Brundtlandrapport.

Verdenskommissionen for Kultur og Udvikling. (Originaltitel: Our Creative Diversity. UNESCO 1995 og 1996). Dansk udgave : Mellemfolkeligt Samvirke 1998.

Hudson, K.: What I think of as my Heritage. Nordisk Museologi, 1, 1998, p.9-16.

Johnsson, Marita: Monumentvairdens begynnelse. Restaurering och friläggning av antika monument $i$ Rom 1800-1830. Acta Universalis Upsaliensis. Figura. Nova Series 16, Uppsala 1976.

Jokilehto, Jukka : A History of Architectural Conservation. Vol.I-III. Ph.D.Thesis, University of York, 1986. (ikke publ. Fotokopi på Konservatorskolen).

Jokilehto, Jukka: Conservation principles and their theoretical background. Durability of Building Materials, 5, 1988 p.267-277. Elsewier Science Publications, Amsterdam 1988.

Jokilehto, Jukka: Cultural Heritage. Diversity and authenticity. ICCROM, December 1994. (ikke publiceret forelæsning. Fotokopi på Konservatorskolens bibl.).

Jokilehto, Jukka : Conservation Ethics. The Seven Lamps. Lecture delivered at Edinburgh,
23.March 1994 (ikke publ.).

Larsen, K.E. og N.Marstein (ed.): Conference on Authenticity in Relation to the World Heritage Convention. Preparatory Workshop, Bergen, Norway 1994. Oslo 1994.

Larsen, K.E. (ed.): The Nara Conference on Authenticity in Relation to the World Heritage Convention. Nara, Japan, 1-6-November 1994. Publ.by UNESCO, ICCROM, ICOMOS, Agency for Cultural Affairs, Japan 1994.

Panofsky, E. and Fritz Saxl: A Late Antique Religious symbol in works by Holbein and Titian. The Burlington Magazine XLIX, 1926 p.177 ff.

Pevsner, N.: Ruskin and Viollet-le-Duc. Walther Neurath Memorial Lecture. Thames and Hudson, London 1969.

Readings in Conservation I. Historical and Philosophical Issues in the Conservation of Cultural Heritage. Ed. By: Nicolas Stanley Price m.fl.The Getty Conservation Institute. Los Angeles 1996.

Shared Responsibility. National Gallery of Ottawa,

Canada, 1989. Ottawa 1990.

Schiessl,U.: The Conservator-Restorer. A Short History of his Profession and Principles. Jubilee Symposium. School of Conservation. Copenhagen 1998, p.139-157.

Tsudi-Madsen, S.: Restoration and anti-restoration. A study in English restoration philosophy.

Universitetsforlaget. Oslo, Bergen, Tromsø 1976.

Witt, T.: Kulturarv - Hvad taler vi om? Nordisk Museologi, 1, 1998, p.17-24

De internationale dokumenter på bevaringsområdet findes bl.a. på internet:

Dokumenter i UNESCO-regi:www.unesco.org

Dokumenter i ICOMOS-regi: www.icomos.org 
Beate Knuth Federspiel

Cultural Heritage and Incentives for preservation

The paper attempts to provide a historical view of how people have related to 'cultural heritage' through the ages - how it was treated, what were the incentives for preserving cultural property and what ideas governed the view of the past. It discusses the meaning of the concept 'cultural heritage' from the beginning of this century focussing on the recent conceptions expressed in The Nara Document on Authenticity, 1994, and the report: Our Creative Diversity from the World Commission on Culture and Development, established under the auspices of Unesco in 1992. This report was published in 1995.

Beate Knuth Federspiel er konservator uddannet ved Det Kgl.Danske Kunstakademi, hvor hun underviser bl.a. i bevaringshistorie og -filosofi, samt i historiske maleteknikker og restaurering.

Adr: Kunstakademiets Konservatorskole,

Esplanaden 34, 1263 Kobenhavn $K$

Fax: +45-33 744777

E-mail:bkf@kons.dk 